\title{
The Historical Evolution of ASEAN and Regionalism in Southeast Asia: With a Special Reference to ASEAN's Role in the Cambodian Conflict (1978-1989)
}

\author{
Kyu-Deug Hwang \\ Associate Professor, College of International Area Studies, Hankuk University of Foreign Studies, \\ kyudeug@hufs.ac.kr
}

\begin{abstract}
In 1967, when the Association of Southeast Asian Nations (ASEAN) was established, its members (then Indonesia, Malaysia, the Philippines, Singapore and Thailand; Brunei joined in 1984) found themselves plagued by a wide range of security problems. These included intra-regional conflicts, domestic instability, extra-regional intervention, and latent inter-ethnic tensions. It was not accidental that the ASEAN states as a group of newly independent (with the exception of Thailand, which had never been a colony) developing countries prioritized 'respect for the sovereignty and territorial integrity of all states' and 'non-interference in the affairs of States'. Rather, the commitment of ASEAN members to the principle of the modern Westphalian state system should be understood in the context of the search for internal stability and regime security as newly independent countries engaged in nation-building and state-making. What made ASEAN politico-security regionalism (driven by nation-state centrism) really distinctive were the norms and values which came to be known as the 'ASEAN Way', Within the ASEAN Way context, in particular, this article explores ASEAN's role in the Cambodian conflict (1978-1989) for the purpose of tracing the scope of which it contributed to the consolidation of ASEAN's norms and principles regarding the way of conflict management in Southeast Asia. Indeed, ASEAN had considered the feasibility of accepting Vietnam (as well as Laos and Cambodia) within its group. However, Vietnam's invasion of Cambodia in December 1978 undermined an initial idea on the part of ASEAN to include Vietnam within its regional grouping. Therefore, by 1978 the intensifying conflict between Vietnam (supported by the Soviet Union) and Cambodia (backed by China) was a great difficulty to ASEAN for achieving the goal of 'One Southeast Asia' concept through including the rest of Southeast Asia. Against this background, this article analyses the creation, evolution and process of ASEAN politico-security regionalism up to the end of Cold War in order to highlight ASEAN's approach to conflict management in the Cambodian crisis.
\end{abstract}

Key words: Historical Evolution, ASEAN, Regionalism, ASEAN Way, Cambodian Conflict, Southeast Asia

DOI: $10.7176 /$ JAAS/58-12

Publication date:November $30^{\text {th }} 2019$

\section{Introduction}

In 1967, when the Association of Southeast Asian Nations (ASEAN) was established, its members (then Indonesia, Malaysia, the Philippines, Singapore and Thailand; Brunei joined in 1984) found themselves plagued by a wide range of security problems. These included intra-regional conflicts, domestic instability, extra-regional intervention, and latent inter-ethnic tensions (Acharya, 2000: 83-96). These states were disparate in terms of their geographical size, ethnic composition, socio-cultural identity, colonial experience and post-colonial polities (cf Legge, 1992:1-50). ASEAN, typical of post-colonial developing states' organization, reflected that its composition was of 'weak states', whose '...domestic insecurity frequently spills over to disrupt the security of neighbors' (Buzan, 1991:46). Since socio-cultural diversity and political heterogeneity in Southeast Asia had militated against the search for regional identity built through 'regionalism', i.e. regional cooperation or a regional scheme, it had to be constructed through 'interactions'. According to Acharya (2001:47), 'such interactions could only be purposeful if they were consistent and rule based. ... To this end, ASEAN's founders over a period of a decade from its inception adopted and specified a set of norms for intra-regional relations'.

It was not accidental that the ASEAN states as a group of newly independent (with the exception of Thailand, which had never been a colony) developing countries prioritized 'respect for the sovereignty and territorial integrity of all states' and 'non-interference in the affairs of States'. Rather, the commitment of ASEAN members to the principle of the modern Westphalian state system should be understood in the context of the search for internal stability and regime security as newly independent countries engaged in nation-building and statemaking (Acharaya, 2001:57-58). What made ASEAN politico-security regionalism (driven by nation-state centrism) really distinctive were the norms and values which came to be known as the 'ASEAN Way', that will 
be discussed in the following sections.

Within the ASEAN Way context, in particular, this article explores ASEAN's role in the Cambodian conflict (1978-1989) for the purpose of tracing the scope of which it contributed to the consolidation of ASEAN's norms and principles regarding the way of conflict management in Southeast Asia. Indeed, ASEAN had considered the feasibility of accepting Vietnam (as well as Laos and Cambodia) within its group. However, Vietnam's invasion of Cambodia in December 1978 undermined an initial idea on the part of ASEAN to include Vietnam within its regional grouping. Therefore, by 1978 the intensifying conflict between Vietnam (supported by the Soviet Union) and Cambodia (backed by China) was a great difficulty to ASEAN for achieving the goal of 'One Southeast Asia' concept through including the rest of Southeast Asia (Acharya, 2000:133-157).

In order to highlight ASEAN's approach to conflict management in the Cambodian crisis, this article analyses the creation, evolution and process of ASEAN politico-security regionalism up to the end of Cold War. In the course of the formation and development of the organization in this period, the idea and method of the "ASEAN Way', (which has been considered as the core mechanism to drive the organization since its inception) emerged. Norms such as musyawarah (consultation) and mufakat (consensus), which were seen as important components to form the idea of the 'ASEAN Way', brought forth the sense of collective identity based primarily on regional politico-security, instead of economic, cooperation. Under the great powers' influence, moreover, ASEAN states sought to make a strong commitment to other important norms and principles such as mutual non-interference, non-intervention, non-use of force and regional autonomy.

During the Cambodian crisis (1978-1989), the value and meaning of these norms were tested by the policy of not only isolating Vietnam, but also engaging outside powers in regional affairs. Nonetheless, these norms, since the outset of ASEAN, have been instrumental in evolving and shaping ASEAN regionalism. In this article, thus, the emergence of the 'ASEAN Way' will be highlighted in order to comprehend the fundamental nature and type of ASEAN regionalism. This will be discussed by exploring the effects and limits of ASEAN's collective identity as a response to the regional disputes, tensions and conflicts which took place during the Cold War. This historical and contextual sketch is necessary for the understanding of ongoing processes of contemporary ASEAN regionalism.

\section{The Origin of ASEAN Regionalism}

The pre-colonial patterns of Southeast Asia teemed with a great deal of political diversity and external influences. In particular, external influences such as Indian and Chinese cultural influences transmitted through trade were a key factor in polarizing the region. These influences contributed to the division of Southeast Asia's political economy into an inland-agrarian segment, and a coastal commercial segment. Nonetheless, at least two major features of Southeast Asian history before the arrival of the Europeans offer the possibility of a regional framework: 'the first is an inter-state system which was loosely defined and constantly changing, but it did include much of what we call Southeast Asia today; the second is a highly dynamic pattern of commercial interaction' (Acharya, 1999a:58-9; 2000:18-29). As noted in the argument of Fawcett (1995), it can be said that few, if any, regions, are totally natural and pre-ordained: rather, they are socially constructed. In that regard, the pre-colonial Southeast Asia cannot be considered as having been devoid of any common political, cultural, or economic space.

A number of aspects of the historical evolution of Southeast Asia, however, militated against the appearance of any sense of regional identity. Indeed, the term 'Southeast Asia' which is of recent origin and usage emerged as a visible entity distinct from the rest of Asia only after the Second World War, albeit the term designated the theatre of war commanded by Lord Mountbatten during the war. By the nineteenth century, the Western colonial powers had come to dominate the region and their influence became a barrier to the development of any kind of regional identification or sentiment. In 1940, following the defeat of France by Germany, Germany's ally Japan expelled the European powers and secured access to French Indochina and took control of the colony's exports (Rigg, 1991:29-32).

However, once the war ended, the expectations that the independence of the people of Southeast Asia was at hand would ensure that the process of decolonization continued. With the exception of Thailand, the other countries of Southeast Asia were colonized by foreign powers, but the Southeast Asian states gradually achieved formal independence. Nonetheless, even after its independence, Southeast Asia remained an unstable and volatile area in the Cold War rivalry between the United States and the Soviet Union, as well as a battlefield in the conflict between China and the Soviet Union (Narine, 2002:9-10).

The lessons from colonial oppression impacted upon the future ways of how the states of Southeast Asia conceived the regional environment for forming a united front against external forces in terms of political (diplomatic) and ideological dimensions. The colonial experience impressed on the people of the region, in particular the leaders, the reality of the international imperialist system characterized by exploitation and predation. As Narine (2002:10) argues, the suspicions of the Southeast Asian states in the field of international 
relations, as well as the perception of external threat, played a critical role in the shaping of regionalism in Southeast Asia since the colonial period.

In the post-independence era, Southeast Asian states gradually began to witness a number of intra-regional conflicts which had not emerged earlier because these countries had been too pre-occupied with matters at home to be concerned with their neighbors (Huxley, 1996:228-229). Thus, the differences that began to appear in the post-colonial period illuminated the competing claims over territory, boundaries and other creations of the colonial period. These problems created other intra-regional tensions among peoples that had been incorporated into states that did not share their same identifications. In this period, moreover, of the most serious domestic challenges in the region were the threats of communist insurgency and ethnic separatism (Gordon, 1964).

Under these circumstances, throughout the 1950s and 1960s, the major features of the international relations of Southeast Asia were complex interactions between three important forces: nationalism, the decolonization process, and the advent of the Cold War (Acharya, 2000:43-74). While nationalism had helped spur the goal of self-reliance and autonomy from the colonial yoke, it did not resolve the difficulty of national integration or regime legitimacy: 'Southeast Asian countries were 'weak states' suffering from the problematic issues of ethnic divisions and separatism and challenges to regime survival' (Acharya, 2000:55).

Within the unstable environment of the pre-ASEAN period caused by internal factors as well as external factors in the region, there were a number of attempts at regional cooperation in political-security affairs. These attempts began with the establishment of the Southeast Asian Treaty Organization (SEATO) in 1954. SEATO was an American attempt to deter communist expansion into Southeast Asia. It was considered to be the Southeast Asian version of the North Atlantic Treaty Organization (NATO), despite the difference of geostrategic conditions between Southeast Asia and Western Europe. Comprised of a diverse membership with diverse interests including, the US, Britain, France, Australia, New Zealand, Pakistan, Thailand and the Philippines - SEATO was controversial from the beginning, and America was not able to attract broader Asian membership due to Asian concerns about SEATO's overtly anti-communist nature and the dominant role played by the US. In addition to SEATO, the Asia Pacific Council (ASPAC) established in 1966 was a further attempt to create a bloc of anticommunist states in the region at the height of the US involvement in Vietnam, but it also failed to develop widespread support and was allowed to lapse in 1972 (Frost, 1990:2-4).

In response to the failure of SEATO and ASPAC, Southeast Asian states launched their own initiatives for regional cooperation to serve their security interests. Among the earlier attempts were the Association of Southeast Asia (ASA) in 1961 and Malaya-Philipines-Indonesia (MAPHILINDO) in 1963 (for a comprehensive overview of the formation of ASA and MAPHILINDO, see Antolik, 1990:3-21; Frost, 1990:3-6; Irvine, 1982:815; Jorgensen-Dahl, 1982:14-23; 190-212). ASA was the first attempt by the Southeast Asian states to 'promote regional solidarity'. The members of ASA were Malaya, the Philippines, and Thailand. The leaders of these countries shared the belief that regional cooperation was an important instrument to serve their interests instead of relying on external powers to meet their security needs.

In 1962, however, ASA was crippled by the Malaysian-Philippine territorial dispute over British North Borneo, or Sabah, which the British intended to include in the proposed Federation of Malaysia. After the Federation was established in 1963, the ties between Malaysia and Philippines were cut off causing the suspension of ASA until 1965 (Khong, 1997: 329). Nonetheless, as Narine (2002:11) notes, ASA left a legacy to form the basis of the 'ASEAN Way', an approach to regionalism that is at the core of ASEAN's viability.

MAPHILINDO in 1963 was also a regional initiative proposed by Philippines and was referred to by its acronym, which comes from the names of its members, Malaya, the Philippines and Indonesia. In fact, the Philippines and Indonesia regarded MAPHILINDO as a way to block or undermine the proposed Federation of Malaysia, while Malaya considered it as a way to promote the Federation's acceptance by the others. As Gordon (1966:22-25) notes, due to the Indonesia's concern about the 'conspiracy' of Britain to create Malaysia as a symbol of imperialism in the region, as well as the Philippines' Sabah disputes, both the Philippines and Indonesia did not recognize Malaysia. In response, Indonesia began its policy of Konfrantasi (Confrontation) against the Federation, and MAPHILINDO ceased to exist. Thus, after the establishment of the Federation and appearance of confrontation, MAPHILINDO could not develop into any fruitful institutional formation.

Of the intra-regional conflicts of this period, Konfrontasi which was a policy initiated by the Indonesian nationalist leader Sukarno, was the most destabilizing. Konfrontasi highlighted the disruptive power of Indonesia as the largest and militarily most powerful state in the region (Mackie, 1974:318-20). As Alagappa (1991:18) argues, Konfrontasi implies that because Malaysia was seen as a symbol of 'neo-colonialism', Indonesia considered Malaysia as a threat to the territorial integrity of Indonesia. He argues that Indonesia wished to attain an international reputation as a representative of the 'emerging forces' of the developing countries, as opposed to 'reactionary and repressive old established forces'. However, when Sukarno lost control over state power to General Suharto and his military command in 1966, Konfrontasi ended. Konfrontasi was shown to be damaging to the countries involved: Indonesian economic sanctions against Malaysia affected Indonesia as much as its intended target; thus, this provided Suharto with the concerns that the weak economic condition in Indonesia 
might give China and communism an opening in to Indonesia (Antolik, 1990:19).

Thus, as an outcome of the conflict in this period, the states of Southeast Asia started to learn how much more easily shaken and injured they could be when they were antagonistic among themselves. This lesson led them to share a common understanding of the significance of interdependence in dealing with their internal security problems. It further helped generate the need for a regional organization that could tackle the tensions caused by internal as well as external threats. The aspiration for a new organization in the region ultimately evoked the formation of ASEAN.

\section{The Evolution of ASEAN Regionalism}

ASEAN was established on 8 August 1967. Its five founding members were Malaysia, Indonesia, the Philippines, Thailand and Singapore. As mentioned earlier, although ASA and MAPHILINDO - the predecessors of ASEAN - were short-lived, the main objective of these two initial organizations to promote regional solidarity became the basis for creating ASEAN. Indeed, ASEAN has the same organizational structure as that of ASA, and has received most of its projects for implementation from ASA (Solidum, 1974:34).

As the 1967 Bangkok Declaration (see ASEAN 1967) states, ASEAN's aims and purpose were to ensure the survival of its members by enhancing regional peace and stability through abiding by the rule of law in the relationship among states in the region and promoting common interest in the economic, social, cultural, technical, scientific and administrative fields. As Irvine (1982:13) notes, the major objective and purpose of the organization illustrate the focus on cooperation in the economic, social, and cultural areas. Of these, economic cooperation was given the highest priority because the member countries considered it as an essential prerequisite for the achievement of cooperation in other areas. But the ambitions of ASEAN states in the area of economic cooperation were very modest and futile. In fact, the key factors behind the focus on economic cooperation, as well as social and cultural areas were relatively less controversial compared to political or security cooperation.

Irvine (1982:14) goes on to argue that although political cooperation was played down in the ASEAN Declaration, there are good foundations for the view that they were of primary significance in the minds of most delegations participating in ASEAN's inaugural meeting. Though the norms and principles that were outlined in the preamble of the Declaration are quite broadly stated, they propose at least the rudiments of a common political program for the organization. The fact that security matters or political controversies were dealt with by ASEAN delegates in 'private sessions' was considered as 'informal' discussions.

From the start, ASEAN's aims and methods were multi-dimensional: economic prosperity, social equity, cultural progress and regional peace and stability were to be accomplished via joint efforts. The founding document implied that each of these sectors had 'spill-over effects'. 'ASEAN was not just a regional economic group like European Community style; nor was economic integration ever a goal. It was also not a military alliance like NATO' (Khong, 1997:326). In other words, Khong argues that economic growth, consultative ways, methods of consensus, dialogue, cultural exchanges and diplomatic reassurances were all considered as contributing to the overall idea of security instead of viewing ASEAN security in a completely military or in a deterrence sense.

While ASEAN claimed responsibility for maintaining the region's stability and peace free from external interference, it rejected military means to achieve this goal. Instead, its approach was encapsulated in the Indonesian concept of 'regional resilience', which would stem from 'national resilience' based on the strengthening of all the elements in the development of a nation in its entirety, thus consisting of resilience in the ideological, political, economic, social, cultural and military arenas (Henderson, 1999:17; also Leifer, 1989:4). According to Dewitt's argument cited by Khong (1997:326), in the terminology of post-Cold War expressions on Southeast Asia's security, from the outset, ASEAN may be perceived to have adhered to the idea of comprehensive security.

Although some scholars (Buzan, 1988; Frost, 1990) have argued that the formation of ASEAN was aimed at creating a group of anti-communist states in a volatile region, others (Acharya, 1998; Irvine, 1982; Khong, 1997; Leifer, 1989) have pointed out that ASEAN member countries were not meant to be a military alliance-oriented security group. In this period, as Leifer (1989:5) notes, the member states were only too conscious of the danger of provoking a violent reaction through a premature attempt to confront the problems of regional security head on in forming a military alliance. He continues to argue that an alliance in the region was out of the question not only because of the lack of military capability but also because of the effort to encourage the spirit of nonaligned status.

In fact, the significant factor behind the evolution of ASEAN regionalism, as already noted, was a common sense of vulnerability to the enemy within, for example, the threat of communist insurgency and ethnic separatism. Furthermore, in Alagappa's argument cited by Acharya (1998:203-204), the security perceptions of ASEAN members were and continue to be, 'inward-looking' in which overcoming insurgency and preventing a recurrence of intra-mural disputes took precedence over organizing an alliance against a common external threat. 
For instance, a number of sources of intra-regional disputes in Southeast Asia can be divided into two categories: The first relates to the spillover effect of domestic challenges, particularly ethnic, political and ideological conflicts to state structure and regime security; the second concerns disputes over territory. These include the Malaysia-Singapore dispute over the Pulau Batu Puteh/Pedra Branca Island in the Singapore Strait, the Malaysia-Indonesia dispute over the Sipadan and Litigan Islands in the Sulawesi Sea near the Sabah-Kalimantan border, the Thai-Malaysia dispute regarding their common border, the Malaysia-Brunei dispute over Limbang and the Philippines-Malaysia dispute over Sabah (see Acharya, 2001:129-130).

In the early period of ASEAN, Indonesia and Thailand took the initiative of mediation for resolving the hostile relations between Malaysia and the Philippines caused by the Sabah territorial dispute. The initiative was facilitated by the institutional context of ASEAN, which made third-party mediation legitimate and unthreatening. For instance, Indonesia's president Suharto sought to reconcile Malaysia with the Philippines, and his intervention was consultative and an effort to move Malaysia and the Philippines toward a consensus (Khong, 1997:330). From these experiences, a set of procedural norms for the conduct of regional relations began to appear. Norms such as musyawarah (consultation) and mufakat (consensual decision making) became important components of security diplomacy of ASEAN (Jorgenson-Dahl, 1982:166-169; Khong, 1997:330-331; Acharya, 1999b:62-66). Indeed, the conflict management of ASEAN is largely based on the Malay cultural practices of musyawarah and mufakat, which the Indonesians introduced to Southeast Asian diplomacy (Narine, 2002:31). Consultation (musyawarah) means that 'a leader should not act arbitrarily or impose his will, but rather make gentle suggestions of the path a community should follow, being careful always to consult all other participants fully and to take their views and feelings into consideration': and, consensus (mufakat) is 'the goal toward which musyawarah is directed' (Jorgenson-Dahl, 1982:166).

In fact, the idea of consensus is not an abstract notion, but was conceived as a pragmatic way of advancing regional politico-security cooperation in Southeast Asia. That is, the concept was initially applied to overcome hesitancy and indifference among ASEAN members towards regional cooperation (Acharya, 2001:68-69). In this context of ASEAN consensus, Lee Kuan Yew asserted as follows: 'When four agree and one does not, this can still be considered as consensus and the five-minus-one scheme can benefit the participating four without damaging the remaining one' (Cited in Irvine, 1982:62). By implication, thus, this means that the idea of consensus in ASEAN can be seen as a commitment of the members to finding a way of moving forward on the basis of flexibility instead of unanimity. In this context, Solidum (2003:97) argues as follows:

In ASEAN, flexibility accompanies musyawarah and mufakat, for even if everyone had agreed on a certain matter, not everyone is obliged to actually implement it because ASEAN allows bilateral and other arrangements in cooperation. If a member is not ready to participate, his participation in the consensus does not oblige him to act on it. All that is needed is his agreement in principle.

Starting with the cultural practices of musyawarah and mufakat in the region, ASEAN has developed the 'ASEAN Way'. That is, the ASEAN Way is largely viewed as a decision-making process that features a 'high degree of consultation and consensus' (Acharya, 2001:64). In the ASEAN Way context, ASEAN also promotes regional socialization and has facilitated contacts between the governmental elites of its member states. As a result, it has helped construct a sense of regional identity, as well as ties of personal obligation and familiarity among national leaders (Narine, 2002:31). Given the circumstances, it can be argued that the 'ASEAN Way' may largely be seen as the process of regional interactions and cooperation based on norms such as musyawarah (consultation) and mufakat (consensual decision making) which became part of the ASEAN Way. A number of aspects of the ASEAN Way were succinctly provided by Boyce (1973:175) as follows:

- $\quad$ a disposition to summitry, especially through the 1960s (this underlines the highly elitist character of ASEAN decision-making process);

- a dependence on musyawarah principles and concepts in the conduct of high level meetings;

- $\quad$ a preference for veiled and often 'unofficial' preliminary transactions by special agents prior to formal ministerial conferences;

- $\quad$ a preference for an informality and ad hoc basis in decision-making procedures;

- $\quad$ an avoidance of legal machinery for the settlement of disputes;

- $\quad$ readiness to accept mediation or good offices from friendly third parties in the region;

- a tendency of at least three ASEAN members (Malaysia, Indonesia and the Philippines) to use the recall of an envoy or down-grading of a mission as a diplomatic practice.

With regard to conflict management, given the elements of the ASEAN Way mentioned above, Amer (1999:1036) argues that ASEAN's approach has been geared more towards conflict avoidance and/or prevention 
rather than conflict resolution. In reality, that is, neither did ASEAN resolve the Sabah dispute, nor ASEAN play the role of conflict manager in a formal and legalistic way. Through direct and indirect measures of diplomacy, dialogue, restraint and pressure, nonetheless, ASEAN could prevent any further escalation of the tension that might have led to armed hostilities and even war (Acharya, 2000:93; 2001:50).

In this early period of ASEAN, therefore, the outcome of consultations and the movement toward consensus and dialogue may be regarded as a cornerstone of collective identity generated by their security interdependence in ASEAN politico-security regionalism. For ASEAN, as Khong (1997:332) puts it, 'the sense of collective (regional) identity was based primarily on security, not economic, cooperation'. But ASEAN's ability to continue with its consultations and to create consensus was tested by the policy of isolating Vietnam. Indeed, ASEAN's strategy of isolating Vietnam is a good example of the significance of norms and of ASEAN coherence and solidarity. ASEAN norms which would regulate regional relations - respect for the territorial integrity and sovereignty of neighbors - had been violated by Vietnam during the times from Vietnam's invasion of Cambodia in 1978 until the withdrawal of Vietnamese troops from Cambodia in 1989 (Khong, 1997:333-335).

Under these circumstances, the ASEAN states also faced the challenges to drive and decide what type of regional (security) order was appropriate based on a set of norms and principles that would be acceptable to external actors as well as internal in Southeast Asia. In other words, notwithstanding all the intra-regional security issues, ASEAN also had to manage external challenges in a Cold War regional environment. In particular, the invasion and the decade-long occupation of Cambodia by Vietnamese forces left the challenge of responding to the great powers' influence and rivalry in the region. Thus, the common sense that regional conflicts not handled at the regional level would open the door to the outside powers' intervention, which in turn would worsen existing intra-regional tensions.

To this end, ASEAN members emphasized the ASEAN style of security regionalism with highlighting the principles of non-interference, non-intervention, and non-use of force. The focus of ASEAN members on these principles intensified further as the external powers' influences changed, especially after the withdrawal of US forces in Vietnam. Therefore, as Acharya (2000:98-99; 2001:80-82) notes, through the Declaration on a Zone of Peace, Freedom and Neutrality (ZOPFAN) in Southeast Asia, ASEAN leaders attempted to accomplish regional autonomy by providing 'regional solutions to regional problems' and illuminating its concern with the danger of great power intervention and the necessity for enhanced security self-reliance as the basis of ASEAN's collective regional identity, which will be further discussed in the following sections.

\section{ASEAN's Collective Identity: norms and principles}

Between 1976 and 1989, ASEAN's policy against Vietnam required China's help to keep the pressure on Vietnam at the Vietnamese-Chinese border and to support the Cambodian resistance against Vietnam. However, ASEAN's strategy of isolating Vietnam conflicted with the different perceptions of member states' strategic interests. Both Malaysia and Indonesia considered China as a greater threat to ASEAN than Vietnam. Thus, while they wanted Vietnam to withdraw from Cambodia, they wished to see a Vietnam that was strong enough to play a balancing role against China (Khong, 1997:334). As Henderson (1999:18) notes, ASEAN members were divided over the practical implications of the Bangkok Declaration's proscription against external interference in managing regional affairs. In 1970, under these circumstances, Malaysia proposed that ASEAN should be 'neutralized' under the guarantee of the major powers. But, the proposal was rejected by Indonesia because neutrality at the 'diktat' of the major powers ran contrary to its concept of regional resilience, and was met with concern by both the Philippines and Singapore since it could prejudice America's regional presence.

Nonetheless, in 1971, ASEAN members agreed to the proposal for the creation of the Declaration on a Zone of Peace, Freedom and Neutrality (ZOPFAN) in Southeast Asia. It was supported by the two notable agreements in 1976, the Declaration of ASEAN Concord and the Treaty of Amity and Cooperation (TAC) in Southeast Asia. Subsequently, in 1995, the idea for a Southeast Asian Nuclear Weapons-Free Zone (SEANWFZ) was also proposed as a way of realizing the goal of ZOPFAN. These declarations and treaties are part of ASEAN's collective identity for managing the internal as well as external challenges. The essence of these ASEAN norms and principles is the conservation of each member's national sovereignty and regional autonomy, which are the core values enshrined in the organization's declarations and treaties. The operative paragraphs of the ZOPFAN Declaration are:

- that the member countries are determined to exert efforts to secure the recognition of, and respect for, Southeast Asia as a Zone of Peace, Freedom and Neutrality, free from any form or manner of interference by outside powers;

- $\quad$ that that the member countries should make concerted efforts to broaden the areas of cooperation which would contribute to their strength, solidarity and closer relationship (ZOPFAN Declaration, 1971).

According to the ZOPFAN Declaration in 1971, ASEAN states regarded regional neutralization or neutrality as a 
'desirable objective'. But the ZOPFAN restated the principle in the 1967 Bangkok Declaration that the member countries would ensure the region's peace and stability from external interference in any form. Unlike the original neutralization proposal produced by the Bangkok Declaration in 1967, although the principles regarding foreign military alliance and bases have never been seriously pursued, ASEAN has managed to keep the concept active through 'verbal manipulation'. For instance, Singapore, Malaysia and other ASEAN states supported cooperation with the US navy through 'access arrangements', while rejecting the need for foreign military bases, while an Australian-Indonesia agreement providing for mutual consultations in the event of external threats is described as a 'security agreement', not an 'alliance' (Acharya, 2001:55). Although the ZOPFAN Declaration did not achieve genuine neutralization of Southeast Asia, it was meaningful for being ASEAN's initial attempt to respond to global and regional environments heavily penetrated by the intervening great power(s). Moreover, the ZOPFAN included all the major security considerations which underpinned the evolution of ASEAN, including the norms of non-interference, non-use of force and regional autonomy.

Under the ZOPFAN Declaration, the ASEAN member countries would be expected to abide by the basic norms and principles in managing their external relations. In addition, the ZOPFAN proposal implied that rivalry among outside powers was the main possible cause of polarization and instability in Southeast Asia. Moreover, it assumed that member states left to themselves in the region would be able to resolve their conflicts smoothly (Leifer, 1989:7-11; 163-164). However, the tension between the ASEAN members' hopes for regional security autonomy and the continued dependence of some of them on external security guarantees have remained the major stumbling block in the way of realizing ZOPFAN: with the Philippines and Thailand emphasizing the need for external security relationship with the US as opposed to the pro-neutralization views of Malaysia and Indonesia; Singapore preferred to trust its security to a balance of great powers in the region. Each state had a different interpretation of what ZOPFAN meant and implied (Narine, 2002:22).

Despite the ambiguity and ineffectiveness of ZOPFAN, as well as the tensions between the ASEAN members caused by the different strategic interests of different members, the ASEAN members continued to promote the idea of ZOPFAN. The ZOPFAN committed the ASEAN states to avoid alliances with outside powers, to eschew giving consent to foreign powers' intervention in the domestic affairs of the regional states, to evade involvement in any conflict of powers outside the zone, and to confirm the removal of foreign military bases in ASEAN (Hanggi, 1991:25).

Moreover, the Declaration of ASEAN Concord in 1976 underscored the significance of ZOPFAN as an ideal. In this declaration (see ASEAN 1976a), the concept of 'ASEAN resilience' as an essential component of ASEAN's approach to regional peace and security was introduced. As mentioned earlier, the ASEAN members regarded regional security as a comprehensive concept that starts from national stability and peace, that is national resilience. In this sense, without national resilience as well as regional resilience, the ASEAN states would be too feeble to manage conflicts caused by outside power rivalries in the region. Hence, ASEAN resilience was seen as the essential component for ZOPFAN to be effective. Although there are criticisms and flaws indicated by some scholars regarding the emergence of ASEAN's collective identity, as we have seen so far, the collective identity in ASEAN security regionalism can be ascertained within and through a process and framework of ASEAN's ideal, norms and principles with which the member states gradually stepped up a 'regional resilience' in order to lessen the possibility of outside intervention and use of force in international relations.

In the formation of a collective identity in ASEAN, Acharya (1998:208-213) points out four elements. These elements can be summarized as follows. First, the contribution of multilateralism to ASEAN regionalism lies not in providing a formal institutional mechanism for conflict resolution, but rather in promoting the process of elites socialization. Border disputes between Malaysia and Thailand, or Malaysia and the Philippines were handled by bilateral channels. But, such bilateralism has not been exclusionary, or directed against another ASEAN member, but rather has served as a complement to multilateralism. Through the norms of musyawarah and mufakat, as was witnessed in the case of Sabah dispute, Indonesia's president Suharto as a third-party sought to reconcile the hostile relations between Malaysia and the Philippines. Second, the ASEAN symbols, so called 'ASEAN Spirit' and the 'ASEAN Way', have been invoked on a number of occasions to reduce intra-mural tensions. Through the symbol of the 'ASEAN Way', ASEAN states have claimed to have developed an approach to conflict-reduction within the grouping instead of an approach to conflict-resolution. Third, the development of basic rules of interstate relations within ASEAN, for instance, the normative framework of ASEAN served as the basis of its collective opposition to Vietnam's invasion and occupation of Cambodia during the 1978-89 period. A fourth factor in the formation of collective identity in ASEAN is ASEAN's quest for regional autonomy with pursuing 'regional solutions to regional problems'. While the first and second factors were discussed in the previous sections, the third and fourth factors will be further discussed in the next section, highlighting ASEAN's role in the Cambodian conflict for the purpose of tracing the extent to which it contributed to the consolidation of ASEAN' norms and principles regarding the peaceful settlement of regional conflicts without interference by great powers. In doing so, it will show how ASEAN responded to the Cambodian conflict precipitated by Vietnam's invasion and why it changed its institutional norms which have been prioritized from the first decade 
of the organization's existence.

\section{ASEAN's Security Diplomacy: the Cambodian conflict (1978-1989)}

By 1978 the intensifying conflict between Vietnam (supported by the Soviet Union) and Cambodia (backed by China) was a great difficulty to ASEAN for achieving the extension of its framework of regional order to include the rest of Southeast Asia. ASEAN had considered the feasibility of accepting Vietnam (as well as Laos and Cambodia) within its group. The Bangkok Declaration which established ASEAN talked of the organization being 'open for participation to all states in the Southeast Asian region' (see ASEAN 1967). However, Vietnam's invasion of Cambodia in December 1978 swept away an initial idea on the part of ASEAN to include Vietnam within its regional grouping. Moreover, the action taken by Vietnam was a major setback to ASEAN's doctrine of regional autonomy. In comparison with the regional disputes and tensions in earlier period of ASEAN, as Acharya (2000:111-113; 2001:80-81) notes, the Cambodian conflict caused by Vietnam's intervention retained much broader implications not only with 'a local conflict' but also with 'Sino-Vietnamese, Sino-Soviet and USSoviet rivalries'. That is, the heightened great power rivalry crushed the ASEAN's aspirations for a diminished role of outside powers in Southeast Asia.

As mentioned earlier, the Cambodian conflict caused by Vietnam was marked by a tension between two different approaches. One was to seek to address the regional crisis within a regional framework in which the role of external powers would be reduced. This was supported by Indonesia and Malaysia and was upholding ASEAN's norm of regional solutions for regional problems, with minimal interference of great powers. The other was to seek Vietnam's isolation from the international community and to raise the diplomatic and military costs of its occupation of Cambodia. The latter approach, favored by Singapore and Thailand, included ASEAN's desire to punish Vietnam with forming a resistance coalition front against Vietnam, as well as occasional proposals for intra-ASEAN military cooperation, thereby drawing ASEAN closer to a violation of its norm against military pacts. It also implied pursuing support from the major external powers, thereby deteriorating the norm of regional autonomy. Moreover, as these two polarized divisions were often in conflict, they endangered ASEAN's norm of consultations and consensus through the Cambodian conflict (Frost, 1990:16-17; Khong, 1997:333-334). In terms of these different approaches, Huxley (1990:91) also identifies them with two strands in ASEAN security thinking: the regionalist and the globalist. The regionalists (Malaysia, Indonesia, and some elements in the Philippines and Thailand) were sympathetic towards Vietnam's conception of regional order and were concerned about excluding the military influence of outside powers from Southeast Asia. On the other hand, Singapore's globalist viewpoint, which is also shared by military and political groups in Thailand, considered Vietnam as an expansionist power with close ties to the (then) Soviet Union. The globalists tended to see the importance of linking all the non-communist states of ASEAN with China to organize an anti-Soviet alliance. They did not see China as a threat to the security of the region under its pragmatic leadership. Indeed, both Singapore and Thailand encouraged Beijing to support the anti-Vietnamese Cambodian resistance, with Bangkok organizing a de facto strategic alliance with China against Vietnam in the conflict over Cambodian. Thus, as Acharya (2001:96) puts it, the agony for ASEAN was that 'while the two goals were not mutually exclusive, they created the basis of considerable ambivalence in ASEAN's approach'.

Nonetheless, the Vietnamese invasion and occupation of Cambodian territory helped ASEAN to concretize its primary interests such as non-interference and national sovereignty into definite security concerns for the member countries and to reaffirm the need for ASEAN to strengthen regional solidarity. In fact, for the first decade of ASEAN's existence (1967-1976), the ASEAN members learned to manage their norms and principles in interstate relations with eschewing the use of force and interference. However, the second decade of the organization saw ASEAN's change in response to the Cambodian conflict. In 1976, in response to the communist's victories in Laos and Cambodia, the ASEAN members held their first summit in Bali, Indonesia. The Bali summit of 1976 produced two significant documents: the ASEAN Concord and the Treaty of Amity and Cooperation (TAC). While the Declaration of ASEAN Concord primarily addressed the economic side of security (see ASEAN, 1976a), the TAC focused on the political side of security (see ASEAN, 1976b).

Importantly, in Preamble of the TAC, it is stipulated that 'Desiring to enhance peace ... and mutual cooperation on matters affecting Southeast Asia consistent with the spirit and principles of the Charter of the United Nations ...'. In addition, in Chapter IV of the TAC, devoted to 'Pacific Settlement of Disputes', Article 13 stipulates that 'In case of disputes on matters directly affecting them they shall refrain from threat or use of force and shall at all times settle such disputes among themselves through friendly negotiations' (ASEAN, 1976b). Moreover, Article 15 of the TAC provide for a High Council to 'recommend to the parties in dispute appropriate means of settlement such as good offices, mediation, inquiry or conciliation' (ASEAN, 1976b).

Indeed, in Chapter I of the TAC, dealing with 'Purpose and Principles', Article 2 outlines the fundamental principles which should guide the relations between the signatories to the treaty. The basic principles are as follows: 
- mutual respect for the independence, sovereignty, equality, territorial integrity, and national identity of all nations;

- the right of every state to lead its national existence free from external interference, subversion, and coercion;

- $\quad$ non-interference in the internal affairs of one another;

- $\quad$ settlement of differences or disputes by peaceful means;

- $\quad$ renunciation of threat or use of force;

- $\quad$ and effective cooperation among members (see ASEAN, 1976b).

Given the contents of the TAC, as noted above, Anthony (2003:198) argues that a salient feature of the TAC was its establishment of a 'code of conduct' among regional states according to universally accepted principles, and its provision for the peaceful settlement of disputes. The TAC also has been the only attempt by ASEAN to provide a formal conflict management mechanism in the region. In this context, Narine (2002:23) asserts that the TAC was embodied as the most important norms and values governing the international behavior of the ASEAN states.

Both documents including the Declaration of ASEAN Concord and the TAC in 1976, in fact, broadened the hopes of ASEAN states beyond the organization's initial objectives of economic development and social progress, as shown in the Bangkok Declaration. In 1967 when ASEAN was founded, as already mentioned, the founding members avoided formally and directly addressing political and security concerns. But the communist victories in Indochina compelled the members to prioritize the importance of political and security concerns. In the years of ASEAN's outset, the members were reluctant to establish formal institutions because they preferred an informal and ad hoc style in their cooperation under the pretext of the primary goal of national sovereignty and national resilience. However, the communist's threat provided the incentive for the ASEAN members to install the Secretariat as a permanent body to coordinate the activities and to symbolize the organization's firm commitment to regional cooperation (see ASEAN, 1967; 1976a; 1976b).

During the height of the Cambodian crisis, it threatened to polarize the ASEAN member states into two strands (such as the regionalist and the globalist) and increased ASEAN's dependence on outside powers, thereby eroding the norm of regional autonomy. Nonetheless, as Leifer (1989:12-15) puts it, 'it would be an exaggeration to describe ASEAN as a house divided against itself over the Cambodian conflict: indeed, the government of the Association was obliged to uphold one set in preference to the other, which served as a basis for solidarity and for displaying a quality of diplomatic community'.

Moreover, a series of direct contacts between Indonesia and Vietnam increased ASEAN's flexibility in pursuing possible avenues for discussion over Cambodia. Even the differences of emphasis between ASEAN states, particularly Thailand and Indonesia, did not prevent ASEAN from maintaining a credible image of cohesion over the issue (Frost, 1990:18). Through the event of Cambodian conflict, it was opportune for ASEAN to increase its international prestige as a result of successful diplomatic efforts in the UN and to consolidate the organization's cohesion and unity. The Cambodian issue demonstrated that ASEAN could play a significant role in the region, albeit one that is based primarily on political consultation and consensus building rather than collective military strategy (Frost, 1990:16-18).

However, Huxley (1990:90) points out a number of disadvantages caused by the Cambodian crisis for ASEAN: distracting ASEAN from its original objectives, in particular its aim of national and regional resilience; contributing to the growth of militarism at the expense of political responsiveness; damaging the prospects for peaceful cooperation in the region by dividing Southeast Asia into non-communist ASEAN versus communist Indochinese states; increasing the influence of both China and the former Soviet Union to interfere in the region, which also meant increasing the level of dependence by individual ASEAN states on the US; risking a military confrontation with Vietnam; and exacerbating the Indochinese refugee problems in the region.

Indeed, although ASEAN was established so as to respond to both internal and external threats, the organization in the Bangkok Declaration 'did not see itself as a mechanism for formal dealings with the outside world' (Gyngell, 1982:115). But the negative factors caused by the Cambodian conflict forced ASEAN to change its organizational method with outside powers. According to Alagappa's earlier argument, the ASEAN members' security perception continues to be 'inward-looking', (focusing on intra-regional disputes rather on a military alliance against a common external threat). I agree with his argument partly in terms of ASEAN's shunning off a martial character in its security sense. Yet I do not subscribe to the assertion that the ASEAN members' security perception continues to be 'inward-looking', but I argue that the organization also became 'outward-looking' (in broad spectrum) to cope with external relationships since the Cambodian conflict.

The new threats emanating from the Cambodian issue, (identified above by Huxley), made ASEAN to move from its existing norms to new norms to stabilize the changing situation in the region. As Acharya (2001:97) puts it, the ASEAN states utilized China's intervention and support against Vietnam to punish Hanoi for its use of 
force in Cambodia at the expense of its norm of regional autonomy providing 'regional solution to regional problems'. Thus, as Hoang (2002:185-186) argues, ASEAN's involvement in the Cambodian issue was 'both a deviation from and a reflection of the norm of non-interference: ASEAN deviated from its norms of regional autonomy and the pacific settlement of disputes with the hope that a combination of political, economic and military pressure would force Vietnam to change its position in Cambodia'. In other words, ASEAN advanced norms that helped the member states forge a common position toward the Cambodian issue.

Hoang (2002:192) argues that in the process of coordinating their strategies toward the Cambodian conflict, the ASEAN members upgraded the norms of consultation and consensus-building with offering a regional framework for conflict settlement while utilizing the intervention of outside powers to pressure Vietnam to withdraw from Cambodia. Apart from coordinating their strategies, the norms were essential because ASEAN states differed on how they should balance a regionalist approach with a globalist one.

For ASEAN, a major element in the consensus-building process is the need to offer a united front vis-a vis external actors. While ASEAN states can disagree on a certain position behind the scenes, they keep from parading these differences in public, in particular while dealing with the outside world. It springs from the recognition that regional unity is essential to overcome the weakness and limitations of individual ASEAN states. ASEAN states conceive themselves as weak states in an international system dominated by strong powers. Acting in their individual capability, they cannot expect to influence the behavior of outside powers or further their national interests and objectives. Thus, the collective action helps the ASEAN members to achieve consensus on issues over which they might otherwise disagree.

Nonetheless, a significant point about consensus building is that national interests are in part determined by the need to remain part of the consensus, being considered a friendly neighbor, not frustrating the 'community', and so forth. In this sense, the definition of what forges national interest may change with the process and progress of interaction and socialization among the member states, and the possible tension between the national and the community aims may be reduced. This general feature of Constructivist international relations theory, that the 'social identities' of the member countries are constructed by their interests, may be applicable to the ASEAN case (Acharya, 1999b:63-66).

With regard to the norms of consultation and consensus in the Cambodian conflict, the communiqués produced at the formal and informal ASEAN meetings were utilized to insulate disagreeing and inharmonious concerns with a view to creating a common understanding of the problem which can be considered as consensus-building in the ASEAN way. For instance, ASEAN appointed Indonesia as the organization's official spokesman to Vietnam so that Indonesia's leadership in the Cambodian issues would reduce the role of external actors and pursue a vision of 'One Southeast Asia' which would encompass the Indochinese states (Antolik, 1990:135). Hence, the norms of consultation and consensus were ascribed to the need for ASEAN to form a common stance in response to the regional crisis of the Cambodian conflict.

Although ASEAN faced the formidable challenge to seek a conflict settlement within a regional framework that would require sustaining its norms, the ASEAN leaders realized that the political, social and military end-result of Vietnam's invasion was the limit to their ability to resolve the crisis without the involvement of external actors. As Huxley (1993:16) points out, ASEAN's stance in opposition to Vietnam's role in Cambodia during the 1980s necessitated that the organization and its members go against the principle of the ZOPFAN framework by aligning themselves with China and the West against Vietnam and the Soviet Union. This illuminated that ASEAN's decision to rely on the foreign powers to resolve the Cambodian crisis undermined the ideal of ZOPFAN as an ASEAN's major framework, which asserted the regional autonomy free from the outside powers' interference.

Nevertheless, the regional crisis posed by Vietnam motivated the ASEAN leaders to see the need to change their initial norms and principles to deal with much more complex and destabilizing effects of the Cambodian issues. Because the Cambodian crisis retained much broader implications than the regional disputes and tensions in an earlier period of ASEAN had. According to Acharya's (2001:80-81) assertion, as mentioned earlier, the Cambodian conflict implied not only 'a local conflict' within the Cambodian society but also 'Sino-Vietnamese, Sino-Soviet and US-Soviet rivalries' at the global level. Though the dilemma of ASEAN, under these circumstances, forced the organization to transform into and to develop new norms with coordinating their strategies towards Vietnam and the international community, ASEAN's primary norms of consensus and consultation as a regional framework for regional order were preserved.

\section{Conclusion}

ASEAN's response to the Cambodian conflict during the Cold War had paradoxical effects on its norms and identity. The Cambodian conflict placed ASEAN into the breach of regional autonomy in which ASEAN was obliged to opt for its commitment to a peaceful settlement of the conflict with interference by the outside powers. This means that ASEAN's regional identity in diplomatic unity (which had been tested and transformed by the 
Cambodian conflict) was at the cost of its norm of providing 'regional solutions to regional problems'.

However, ASEAN states responded effectively to the conflict with recognizing the sub-regional milieu of Southeast Asia which was heavily penetrated by the great powers. The ASEAN states acknowledged that they were not only weak powers, but also weak states so that they were unable to resolve the Cambodian conflict by themselves. ASEAN's security priorities were dependent on US and Chinese security guarantees against Vietnamese threat backed by the Soviet Union. Under the auspices of the outside powers' umbrella, ASEAN could spearhead a diplomatic settlement of the conflict in the international arena with utilizing an international campaign to isolate Vietnam.

During the Cold War, therefore, the regional security in Southeast Asia was not static, but dynamic. When decolonization took place in the region, the European intervention largely diminished. Instead, the great powers' influence over the region relatively increased. Following the Second World War, (especially from the inception of ASEAN), the Southeast Asian region was about to evolve gradually out of the stage of 'regional conflict formation' (Väyrynen, 1984:337-359), which was seen as the by-product of colonial legacy. However, a variety of domestic challenges of newly independent states in the region brought forth divisions and conflicts regionally as well as domestically. Typical of these regional and domestic security matters, was an ideologically-based power struggle (ASEAN versus Vietnam) linked to the East-West rivalry. This left a great possibility for external powers to penetrate the regional security.

However, these local hostilities gave the ASEAN members some impetus not only to establish the Declaration on a Zone of Peace, Freedom and Neutrality (ZOPFAN) in Southeast Asia in 1971, but also to take advantage of outside great powers' influence, particularly in the case of Cambodian conflict. As a whole, the creation and evolution of ASEAN did not only reduce threat perceptions among its members with building a collective identity symbolized as the 'ASEAN Way', but also polarize the region with aligning the pro-western and capitalist ASEAN organization against the communist-oriented and Vietnamese-dominated Indochina.

In formulating a regional identity, from the pre-ASEAN era, the idea of region had been expressed and built through a number of interactions made up by the states of ASEAN (for instance, ASA in 1961 and MAPHILINDO in 1963). In this context, the origin of ASEAN security regionalism should not be seen as given, but as constructed by the ASEAN states from the pre-ASEAN era. Moreover, ASEAN (political) security regionalism was shaped in the context of the 'ASEAN Way' during ASEAN's first decade (1967-1976), and reshaped with both a deviation from and a reflection of the principle of regional autonomy, i.e. non-interference, during the period of Cambodian conflict (1978-1989). But this does not imply the renunciation of the sovereignty-bounding regionalism in ASEAN.

Rather, ASEAN states recognized their limits to resolve the Cambodian conflict by themselves so that they could not but manage and settle the conflict with the intention of temporarily allowing the interference of the outside powers. This was ultimately to defend and strengthen ASEAN member states as a group of newly independent (with the exception of Thailand, which had never been a colony) developing countries with putting more emphasis on the idea of sovereignty instead of reducing and abandoning it.

Furthermore, the Cambodian conflict helped pave the way for the much more skilled flexibility of regional organization in and for 'the post-Cold War era which would see an unleashing of conflicts which had been effectively suppressed during the colonial era and the subsequent period of great power rivalry' (Buszynski, 1990:259). Under the new circumstances of the post-Cold War security environment for ASEAN and Southeast Asia, the 'continuity' and 'change' of the organization's principles and norms as a regional framework in response to internal as well as external challenges, need to be illuminated and reconsidered with a view to analyzing the causality of regional security problems and its responses in the further researches.

\section{Acknowledgments}

This work was supported by the Hankuk University of Foreign Studies Research Fund of 2019.

\section{References}

Acharya, A. 1998. Collective Identity and Conflict Management in Southeast Asia. In Security Communities, edited by E. Adler and M. Barnett. Cambridge: Cambridge University Press.

Acharya, A. 1999a. Imagined Proximities: The Making and Unmaking of Southeast Asia as a Region. Southeast Asian Journal of Social Science, 27(1): 55-76.

Acharya, A. 1999b. Culture, Security, Multilateralism: The 'ASEAN Way' and Regional Order. In Culture and Security: Multilateralism, Arms Control and Security Building, edited by K. Krause. London: Frank Cass.

Acharya, A. 2000. The Quest For Identity: International Relations of Southeast Asia. Singapore: Oxford 
University Press.

Acharya, A. 2001. Constructing a Security Community in Southeast Asia, London: Routledge.

Alagappa, M. 1991. The Dynamics of International Security in Southeast Asia: Change and Continuity. Australian Journal of International Affairs, 45:1-37.

Alagappa, M. 1993. Regionalism and the Quest for Security: ASEAN and the Cam bodian Conflict. Journal of International Affairs, 46(2):439-467.

Amer, R. 1999. Conflict Management and Constructive Engagement in ASEAN's Expansion. Third World Quarterly, 20(5):1031-1048.

Anthony, M.C. 2003. The Regionalisation of Peace in Asia. In The United Nations and Regional Security: Europe and Beyond, edited by M. Pugh and W. P. S. Sidhu. Boulder: Lynne Rienner Publishers.

Antolik, M. 1990. ASEAN and the Diplomacy of Accommodation, Armonk, NY: M. E. Sharpe.

ASEAN, 1967. The ASEAN Declaration (Bangkok Declaration), 8 August 1967, Association of Southeast Asian Nations 1967 at http://www.asean.org/view.asp?file=/history/leader67.htm. Accessed: 25 March 2015.

ASEAN, 1976a. Declaration of ASEAN Concord 1976, Association of Southeast Asian Nations 1976 at http://www.asean.or.id/summit/concord.htm. Accessed: 25 March 2015.

ASEAN, 1976b. Treaty of Amity and Cooperation. Association of Southeast Asian Nations 1976b at http://www.asean.or.id/summit/amity76.htm. Accessed: 25 March 2015.

Boyce, P. 1973. The Machinery of Southeast Asian Regional Diplomacy. In New Directions in the International Relations of Southeast Asia: Global Powers and Southeast Asia, edited by Lau Teik Soon. Singapore: Singapore University Press.

Buszynski, L.1990. Declining Superpowers: The Impact on ASEAN. The Pacific Review, 3(3): 259-260.

Buzan, B. 1991. Is international security possible? In New Thinking about Strategy and International Security, edited by K. Booth. London: HarperColins.

Buzan, B. 1988. The Southeast Asian Security Complex. Contemporary Southeast Asia, 10(1): 1-16.

Fawcett, L. 1995. Regionalism in Historical Perspective. In Regionalism in World Politics, edited by L. Fawcett and A. Hurrell. Oxford: Oxford University Press.

Frost, F. 1990. Introduction: ASEAN Since 1967 - Origins, Evolution and Recent Developments. In ASEAN into the 1990s, edited by A. Broinowski. London: Macmillan Press.

Gordon, B. 1964. Problems of Regional Cooperation in Southeast Asia. World Politics, 16(2):222-253.

Gordon, B. 1966. Dimensions of Conflict. Englewood Cliffs, NJ: Prentice-Hall, Inc.

Gyngell, A. 1982. Looking Outwards; ASEAN's External Relations. In Understanding ASEAN, edited by A. Broinowski. New York: St. Martin's Press.

Hanggi, H. 1991. ASEAN and the ZOPFAN Concept. Singapore: Institute of Southeast Asian Studies (ISAS).

Henderson, J. 1999. Reassessing ASEAN. Adelphi Paper, No 328 (May), London: International Institute for Strategic Studies.

Hoang, H. 2002. Outward and Beyond: Institutional Change in Southeast Asia, Ph.D. dissertation, Boston University. 
Huxley, T. 1990. ASEAN Security Cooperation: Past, Present and Future. In ASEAN Into the 1990s, edited by A. Broinowski. New York: St. Martin's Press.

Huxley, T. 1993. Insecurity in the ASEAN Region. Royal United Services Institute for Defence Studies.

Huxley, T. 1996. International Relations. In An Introduction to Southeast Asian Studies, edited by M. Halib and T. Huxley. London: IB Tauris Publishers.

Irvine, R. 1982. The Formative Years of ASEAN: 1967-1975. In Understanding ASEAN, edited by A. Broinowski. New York: St. Martin's Press.

Jorgensen-Dahl, A. 1982. Regional Organisation and Order in Southeast Asia. London: Macmillan Press.

Khong, Y. 1997. ASEAN and the Southeast Asian Security Complex. In Regional Orders: Building Security in a New World, edited by D. A. Lake and P. M. Morgan. University Park, PA: Penn State University Press.

Legge, J. D. 1992. The Writing of Southeast Asian History. In The Cambridge History of Southeast Asia vol.1, Cambridge: Cambridge University Press.

Leifer, M. 1989. ASEAN and the Security of Southeast Asia. London and New York: Routledge.

Mackie, J. A. C. 1974. Konfrontasi: The Indonesia-Malaysia Dispute, 1963-1966. London: Oxford University Press.

Narine, S. 2002. Explaining ASEAN: Regionalism in Southeast Asia. London: Lynne Rienner Publishers.

Rigg, J. 1991. Southeast Asia, A Region in Transition: A thematic human geography of the ASEAN region. London: Unwin Hyman.

Solidum, E. 1974. Towards a Southeast Asian Community. Quezon City: University of the Philippines Press.

Solidum, E. 2003. The Politics of ASEAN: An Introduction to Southeast Asian Regionalism. Singapore: Eastern Universities Press.

Väyrynen, R. 1984. Regional Conflict Formations: An intractable problem of international relations. Journal of Peace Research, 21(4):337-359.

ZOPFAN Declaration, 1971. Zone of Peace, Freedom and Neutrality (ZOPFAN) Declaration, 1971, Malaysia, 27 November 1971 at http://www.aseansec.org/3629.htm. Accessed: 26 July 20015. 